\title{
ReSEARChArticle
}

\section{Liquid medium culture method for rapid multiplication of banana (Musa acuminata) cv. 'GRAND NAINE' through tissue culture}

\author{
G. PRABHULING AND B.N. SATHYANARAYANA
}

\begin{abstract}
SUMMARY
For an increasing number of plantlets, liquid culture methods have demonstrated a number of important advantages over conventional semi-solid micropropagation, including several fold increase in multiplication rate, reduction in medium cost and also space, energy and lobour requirements. These cost-saving advantages have been the driving force for increased attention to the use of liquid systems. Effects of liquid medium using different simple low cost culture containers on in vitro propagation of banana cv. 'GRAND NAINE' were investigated and compared with conventional solid medium. The treatments studied included: Growtech container with nylon wire mesh support; simple polypropylene container with cotton fibre support; simple polypropylene container with partial immersion, simple polypropylene container with full immersion and conventional baby jar bottle with agar gelled medium. Simple polypropylene container with cotton fibre support was found effective than that of agar-gelled medium. The plantlets produced were also sturdier and better quality.
\end{abstract}

Key Words : In vitro, Aseptic cultures, Support matrix, Microshoots, Vitrification

How to cite this article : Prabhuling, G. and Sathyanarayana, B.N. (2017). Liquid medium culture method for rapid multiplication of banana (Musa acuminata) cv. 'GRAND NAINE' through tissue culture. Internat. J. Plant Sci., 12 (1): 85-89, DOI: 10.15740/HAS/ IJPS/12.1/85-89.

Article chronicle : Received : 16.08.2016; Revised : 30.11.2016; Accepted : 27.12.2016

\section{MEMBERS OF THE RESEARCH FORUM}

Author to be contacted :

G. PRABHULING, Center for Horticulture Biotechnology, Directorate of Research, University of Horticultural Sciences, BAGALKOT (KARNATAKA) INDIA

Email: gprabhuling@gmail.com

Address of the Co-authors:

B.N. SATHYANARAYANA, Division of Horticulture, University of Agricultural Sciences, G.K.V.K. BENGALURU (KARNATAKA) INDIA 